\title{
Correction to: Alarm call modification by prairie dogs in the presence of juveniles
}

\author{
Grete E. Wilson-Henjum ${ }^{1}\left[\right.$ ] Jacob R. Job ${ }^{1} \cdot$ Megan F. McKenna ${ }^{2}(-) \cdot$ Graeme Shannon $^{3} \cdot$ George Wittemyer $^{1}(\mathbb{D}$
}

Published online: 20 December 2019

(c) The Author(s) 2019

\section{Correction to: Journal of Ethology (2019) 37:167-174 https://doi.org/10.1007/s10164-018-0582-8}

The article Alarm call modification by prairie dogs in the presence of juveniles, written by Grete E. Wilson-Henjum, Jacob R. Job, Megan F. McKenna, Graeme Shannon and George Wittemyer, was originally published Online First without Open Access. After publication in volume 37, issue 2, pages 167-174 the author decided to opt for Open Choice and to make the article an Open Access publication. Therefore, the copyright of the article has been changed to $\odot$ The Author(s) 2019 and the article is forthwith distributed under the terms of the Creative Commons Attribution 4.0 International License (https://creativecommons.org/licenses/ by/4.0/), which permits use, duplication, adaptation, distribution and reproduction in any medium or format, as long as you give appropriate credit to the original author(s) and

The original article can be found online at https://doi.org/10.1007/ s10164-018-0582-8.

Grete E. Wilson-Henjum

gretewh5@gmail.com

Jacob R. Job

jrjob@rams.colostate.edu

Megan F. McKenna

megan_f_mckenna@nps.gov

Graeme Shannon

g.shannon@bangor.ac.uk

George Wittemyer

G.Wittemyer@colostate.edu

1 Department of Fish, Wildlife, and Conservation Biology, Colorado State University, Fort Collins, CO, USA

2 National Park Service Natural Sounds and Night Skies Division, 1201 Oakridge Drive, Suite 100, Fort Collins, CO 80525, USA

3 School of Natural Sciences, Bangor University, Bangor, UK the source, provide a link to the Creative Commons license, and indicate if changes were made.

The original article has been corrected.

Open Access This article is licensed under a Creative Commons Attribution 4.0 International License, which permits use, sharing, adaptation, distribution and reproduction in any medium or format, as long as you give appropriate credit to the original author(s) and the source, provide a link to the Creative Commons licence, and indicate if changes were made. The images or other third party material in this article are included in the article's Creative Commons licence, unless indicated otherwise in a credit line to the material. If material is not included in the article's Creative Commons licence and your intended use is not permitted by statutory regulation or exceeds the permitted use, you will need to obtain permission directly from the copyright holder. To view a copy of this licence, visit http://creativecommons.org/licenses/by/4.0/.

Publisher's Note Springer Nature remains neutral with regard to jurisdictional claims in published maps and institutional affiliations. 